\title{
Possible Truths Inside Mistranslations-An Attempt at Understanding Mistranslations
}

\author{
Hiromi Sodekawa \\ Aichi Prefectural University, Nagakute, Japan
}

\begin{abstract}
This paper examines five cases of mistranslation to shed light on the deliverability and truthfulness of mistranslations. In some cases, a "mistranslation" turns out to be a brilliant translation. Case 1: At a meeting for the UN Security Council Resolution 242, an intentional mistranslation may have been conducted between English and French texts, so Arab nations and Israel would agree. Case 2: At the time of the Sino-Japan diplomatic normalization, Japanese Prime Minister Tanaka made an apology to China that was mistranslated into something banal sounding. Case 3: During his US visit to see President Reagan, Japanese Prime Minister Nakasone's remarks for an aircraft carrier were mistranslated. Case 4: In TPP negotiations, an ultimatum was pronounced by a Japanese interpreter, although the Japanese negotiator had not said it. Case 5: At a Japanese event, a supposedly deaf composer was dubbed a "digital-age Beethoven" in English; but he replaced it with a "modern-day Beethoven" in Japanese to make himself sound more significant. In hindsight, some cases of mistranslations are hard to judge as mistakes. However, identifying mistranslations helps reveal cultural differences and complicated political differences, and can help improve the quality of translation and interpretation.
\end{abstract}

Keywords: translation, interpreting, mistranslation, truth(fullness), message deliverability

\section{Introduction}

Translation and interpreting which build bridges between one language and another have inevitably produced mistranslations (and sometimes misunderstandings) throughout history. We, in fact, find translation errors in documents and interpreting records, although interpreting is only a spoken language.

Examining word choices in mistranslations, however, sometimes we find the words not so simply "wrong". They may have been carefully chosen, after second or third thoughts, or with specific political intentions in mind. They may look "wrong" on the surface, but in effect capture possible truths in the original meaning. In such a case, we could say that intuitively the "wrong" words were right.

This essay explores five cases of such "mistranslations", discussing their message deliverability and truthfulness.

\section{Case Study of "Mistranslation"}

\section{Case 1}

The UN Security Council has adopted many resolutions ${ }^{1}$ on various security matters in the world since its

\footnotetext{
Hiromi Sodekawa, MA (University of British Columbia, Canada), Associate Professor, Aichi Prefectural University.

${ }^{1}$ United National Security Council Resolution: http://www.un.org/en/sc/documents/resolutions/1967.shtml; http://www.bbc.co.uk/northernireland/learning/history/stateapart/agr eement/agreement/support/ba_c091.shtml; https://en.wikipedia.org/wiki/List_of_war_apology_statements_issu ed_by_Japan; https://www.facinghistory.org/nanjing-atrocities/judgment-memory-legacy/ apology.
} 
launching in 1946. As of October 11, 2018, the number of resolutions has amounted to 2,438. Among them, Resolution $242^{2}$, unanimously adopted on November 22, 1967 in the aftermath of the 3rd Arab-Israeli War, or Six-day War, stands out for its so-called "intentional mistranslation". Because it does not involve Japan and the Japanese language, most Japanese do not know about it. But, as we recently witnessed, a Japanese freelance journalist was released from an extremist Islamic group in Syria in October 2018, so Middle East issues are obviously no longer unrelated to Japan. For this reason alone, the case is worth discussing.

The 3rd Arab-Israeli War, or Six-day War, was fought June 5-10 in 1967 between Israel and the neighboring Arab states. In this six-day battle, Israel seized the Sinai Peninsula from Egypt, the Golan Heights from Syria, and the West Bank from Jordan. Resolution 242 aimed to resolve post-war problems, including the withdrawal of Israeli armed forces from territories occupied and the Palestinian refugees. But the wording of Resolution 242 caused a huge controversy:

(1) English version: Withdrawal of Israeli armed forces from territories occupied in the recent conflict.

(2) French version: Retrait des forces armées israéliennes des territoires occupés lors du récent conflit.

The difference between these two versions lies in the absence of a definite article ("the") in the English version, while the word "des" is present in the French version in the expression of "des territoires occupies", which can only mean "from the occupied territories" (the "des" in front of "territoires occupies" can only be the contraction "from the"). If the meaning of "from some occupied territories" were intended, the only way to say so in French would have been "de territoires occupies". Thus, the French version states that the Israeli armed forces should withdraw from the entire territories they occupied, not from some parts. With or without "the", the meaning is totally different.

Although some have dismissed the controversy by suggesting that the use of the word "des" in the French version is a translation error and should therefore be ignored in interpreting the document, this wording caused confusion. Since both versions are of equal legal force, as officially recognized languages ${ }^{3}$ of the United Nations, the debate has not wound down.

Why did it happen? First and foremost, the UN Security Council must adopt a resolution to help resolve post-war problems. However, both Arab nations and Israel would not budge an inch to give in. Baron Caradon, a British representative, was deeply in trouble as the main negotiator, and is said to have come up with an idea of the two-version solution. Resolution 242 was thus adopted in a tacit agreement between Baron Caradon and other representatives who seemingly pretended not to be aware of the discrepancies.

Chapeau bas (hats off) for Baron Caradon's shrewd diplomacy. As a result, however, we are still faced with the difficulties remaining unresolved. And now, the Middle East is even more in a quagmire in the wake of the Arab Spring, Syria's civil war, a rise and fall of a brutal extremist group, the Islamic State, Yemen's civil war, and so forth.

It is, therefore, not easy to judge whether Baron Caradon's maneuvers were successful or not. But this "translation error" clearly demonstrates some realities and contradictions that Arab nations and Israel face.

Additional note: The Belfast Agreement, or Good Friday Agreement, between the UK and Ireland in 1984 is a peace agreement to solve some of the conflicts in Northern Ireland. It is often referred to as the one with

\footnotetext{
${ }^{2}$ https://en.wikipedia.org/wiki/United_Nations_Security_Council_Re soluti on_242

3 The official languages of the UN are the six languages that are used in UN meetings, and in which all officials UN documents are written. They are Arabic, Chinese, English, Russian, and Spanish. The working languages among them are English and French.
} 
"constructive ambiguity". In other words, the parties concerned are allowed to interpret the sentences or phrases of the agreement at their discretion. It has nothing to do with translation. But "constructive ambiguity" is typical, common nature to this kind of agreement, even in the same language. We may leave some of the actual problems to the next generations, but thanks to this shrewd manipulation of words, we are able to move forward.

\section{Case 2}

On September 25, 1972, Prime Minister Kakuei Tanaka visited Beijing to normalize the Japan-China relations. He was invited to the Great Hall of the People by Chinese Prime Minister Zhou Enlai and attended a banquet there. It had been 27 years since the end of WWII. In his toast, Tanaka made an apology, saying Japan had caused trouble (meiwaku o kaketa) for China during the Sino-Japanese War (1937-1945).

However, Zhou and other dignitaries at the banquet table were astonished and felt insulted by this wording, thinking that "Indeed, Japan feels no remorse. Japan still has a false perception of history". This was because the word meiwaku in Tanaka's remarks was translated into a much less consequential word in Chinese.

In their second meeting, Zhou said to Tanaka that "[the wording] is used only when referring to inconsequential matters". It is used, for example, to say "sorry" when you happen to splash some water onto somebody's clothes. Tanaka then explained in detail what maiwaku o kakeru means to Japanese people, saying "It is a sincere apology from the bottom of our hearts and it means we would not make the same mistakes, and please forgive us. If there is any more appropriate wording in your language, we do not mind using it according to your practices". The discussions went off without a further hitch.

Eventually, the final text of the English version of the Joint Communique of the Government of Japan and the Government of the People's Republic of China reads that "the Japanese side is keenly conscious of the responsibility (sekinin o tsukan) for the serious damage that Japan caused in the past to the Chinese people through the war, and deeply reproaches itself (fukaku hansei)". Still, it does not contain "shazai" or "owabi", two words from the Japanese language connoting a proper apology.

This course of events is suggestive about translation. In order to convey opinions and intentions in other languages, we must be aware of the others' cultures, customs, and history.

Why did this mistranslation occur? There are two considerations. One is that Japanese officials of the Ministry of Foreign Affairs (MFA) might not have had enough knowledge about China and the Chinese language. The other is that the MFA will have known that the Chinese translated word for meiwaku would not express a full apology. But if they had used a word signifying a full apology, it would mean the Japanese side was admitting their wrongdoing to China and then must accept all demands from China. In the latter argument, the MFA might have been a "convicted criminal", pretending to make a translation error. Japan may have snuck their true intention into this.

In the end, due to the lack of a straightforward apology, "an apology from Japan has continued to be demanded", said Susumu Yabuki, a Chinese affairs researcher.

At this juncture, the author would like to add her view on the wording of meiwaku o kakeru. First of all, this wording is the most common and widely used expression for an apology by the Japanese people. It is deeply instilled into their hearts and minds. It is true that strictly speaking meiwaku o kakeru lacks substance as an official apology and that it does not imply taking responsibility. However, the feeling of an apology expressed in these words is deeply sincere. This is because the wording represents a common value of the people, who naturally believe that meiwaku o kakeru implies a violation of fundamental norms in society, and 
which will never be acceptable. However, because it is used so ubiquitously, it has simply become a standard phrase, like "how are you?" in English.

For example, in Japan, when to putting an end to scandals of corruption or harassment by corporations or politicians, almost all of them deeply bow their heads in front of press cameras, saying "meiwaku o kaketa". Japanese fed up with these scenes want to hear more from them, but are there any other fitting phrases than these? Perhaps not. This wording was also heard in the press conference by a freelance journalist, Junpei Yasuda, who was released from Syria's Islamist group, and making an apology to the Japanese government and people (see Case 1) . $^{4}$

Nonetheless, if we want to use meiwaku o kaketa in diplomacy, a detailed explanation as Tanaka gave in the second meeting with Zhou is needed at the outset. Without this explanation, it does not say enough. Thus, the Japanese side failed to convey a clear message of apology to China in this historic moment of the Sino-Japanese diplomatic normalization, which left a bitter legacy. That was indeed unfortunate.

\section{Case 3}

The infamous "unsinkable aircraft carrier" remark, which was believed to be made by Japan's Prime Minister Yasuhiro Nakasone, can never be overlooked in the Japan-US diplomatic history and their associated interpreting. In January 1983, Nakasone visited the US to meet President Ronald Reagan. Ahead of that meeting, Nakasone had a working breakfast with an owner of the Washington Post and others. During this meeting, it was said that Japan would build an "unsinkable aircraft carrier" to prevent Soviet Union bombers from advancing. The Washington Post picked up on this comment in an article the following day, and caused a controversy, suggesting Japan may want to militarize again. The Japanese government officials attending the meeting did not mention this comment at all to their accompanying Japanese press.

"Such a remark was not made" or "Yes, he did say it. We have recorded it". The Japanese government explanations changed again and again. The truth was that Nakasone had said that Japan would make itself like "a big aircraft carrier", which had been translated into "an unsinkable aircraft carrier" by a first-class interpreter, Masumi Muramatsu, who had taken into consideration Nakasone's intention and feelings behind the words, and purposely translated it so. The Washington Post's reporter covered the news based on that translation. For some time, the choice of the word "unsinkable" was regarded as a mistranslation.

In 1989, the author started to work for Simul International. Inc., a leading company of interpreting and translation with Muramatsu as lead director at that time. Workers occasionally chatted about the episode of "unsinkable aircraft carrier". Muramatsu was nonchalant, talking about various episodes related to his interpreting, but he did not say a single word about this one. There was a rumor that the relations between the MFA and Simul had been deteriorating since that incident.

The author personally felt that given the spontaneous nature of interpreting, bashing someone's interpreting in retrospect for "mistranslation" was not fair and too severe. There would have only been a few interpreters, Muramatsu included, to do the job at such a high-level meeting. He was indeed one of the very top interpreters at the time. On the other hand, the author also realizes that any interpreter working as a buffer can easily get into troubled waters.

Many years later, in 2003, Nakasone wrote about translation of the "unsinkable aircraft carrier" in his memoir Jisei Roku [Mediations].

\footnotetext{
${ }^{4}$ See an article of Asahi Shimbun dated November 3, 2018.
} 
...What I meant by that was to make the Japanese archipelago itself a ship, fence high, for emergencies so that it would not allow foreign hostile aircrafts to enter it...The interpreter translated it into an unsinkable aircraft carrier on a sense-for-sense basis. Whoever had translated it, I think their word choice may not have been so different, since I had said it with such a resolute and strong tone....At the time, the Japan-US relations around security were worsening terribly, so a deliberate shock-therapy statement was needed. Just the words "unsinkable aircraft carrier," rather than a million words used to try and express the meaning, created an instant effect. (Nakasone, 2004, pp. 111-115) ${ }^{5}$

Nakasone's mission was meant to exhibit Japan's loyalty to the US, which demanded a significant expansion of Japan's defense force. With the sense-for-sense translation as well as its straightforward report by the Post, Japan's intention was accurately conveyed. From this perspective, this was a masterpiece translation, rather than a mistranslation.

\section{Case 4}

The Asahi Shimbun's article of November 18, 2015, “Keizai Shinwa Kenshou TPP: 1 Ikinari 'saigotsuchou' bei he [Economic In-depth Investigation of the TPP: 1 Abrupt "ultimatum" to the US] is yet another interesting case of mistranslation. Negotiations for the TPP (Trans-Pacific Partnership Agreement), was accelerated with a US initiative in February 2008, but it was only July 2013 that Japan took part in the negotiations, and then much later, in October 2015, when the agreement was concluded. The negotiation was tough and rough from the outset. In particular, the Japan-US negotiation was faced with difficulties to overcome. This garnered major concern, because their combined GDP accounted for $80 \%$ of the total participating 12 countries $^{6}$.

Japanese Economy Minister Akira Amari in charge of the TPP invited Mr. Michael Froman, United States Trade Representative (USTR), to an exquisite Japanese restaurant in Tokyo, when he stopped over in Japan. Amari stressed to Froman, a tough negotiator for tariff elimination, that Japan could not accept a demand of abolishing tariffs on rice and beef due to fierce opposition from farmers. He was said to state, "We would not budge an inch from this point. This is our final response to your demand". Probably pushed by his strong rhetoric, the interpreter translated it into "ultimatum" in English.

Already frustrated Froman got infuriated by this and said, "What on earth are you saying, an ultimatum to your ally?" And he walked out without having dinner. This was the beginning of the TPP negotiations, at the outset, stuck at the very bottom.

An ultimatum means to terminate negotiations if the counterpart does not accept it. The definitions are provided as follows:

(1) A final demand or statement of term, the rejection of which will result in retaliation or a breakdown in relations (The New Oxford Dictionary of English [ODE], 1998).

(2) A final, uncompromising demand or set of terms issued by a party to a dispute. The rejection of which may lead to a severance of relations or to the use of force (Random House Unabridged Dictionary, 1987).

When using the word "ultimatum", it requires care, because its diplomatic definition is clearly established. The author feels sympathy with the interpreter at that meeting, who clearly made a bold translation. However, some may even argue that that interpreter should have known the significance of the word ultimatum, since he or she is entrusted to do the job. Moreover, the author is wondering why the Japanese side did not make every attempt possible not to let Froman go.

\footnotetext{
5 This part was translated from Japanese into English by the author of the essay, Hiromi Sodekawa.

${ }^{6}$ The US Administration of Donald Trump withdrew from the agreement of the TPP in 2017. The other 11 TPP countries reached its revised version in 2018, called Comprehensive and Progressive Agreement for Trans-Pacific Partnership.
} 
Having said this, however, the Japanese stance toward the tariffs on rice was crystal clear. There was no room for compromise. It may not be the case that thanks to this word Japan was spared from tariff abolition on rice, but there is no doubt that the word ultimatum conveyed some truth around the Japanese position. This mistranslation certainly had a high deliverability of message.

\section{Case 5}

The last case in question was not related to politics, but to the Japanese music industry. It was just before the Sochi Olympic Winter Games in 2014 that a piece of music, Sonatine for Violin, was to be used for a short program of a Japanese popular figure skater, Daisuke Takahashi. It was discovered that the piece had not, as previously believed, been composed by a Japanese supposedly-deaf composer, Mamoru Samuragouchi, but rather by a Japanese ghostwriter, Takashi Niigaki. A nonfiction writer, Norio Koyama, made this public in his interview with Niigaki. This was sensational news and drew enormous public attention in Japan.

The scandal also led us back to an interview in TIME, an American magazine, from September 15, 2001. The title was:

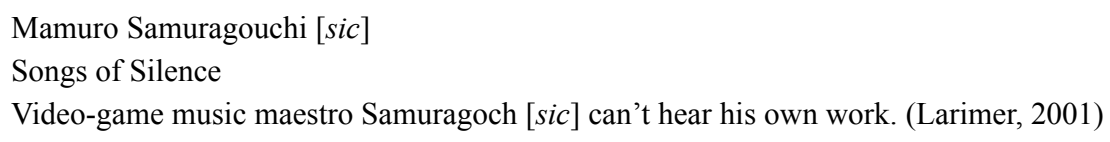

This article was written by Tim Larimer, a British journalist, described Samuragouchi as "a digital-age Beethoven, a deaf composer who overcomes the loss of the sense most vital to his work".

Since Samuratouchi was a composer of video game music, Larimer automatically presented him as "a digital-age Beethoven". So did his manager for its Japanese translation. But this depiction was turned into "a modern-day Beethoven" since who-knows-when. NHK's special program on Samuragouchi aired in March 2013 also employed "a modern-day Beethoven" to describe him. As Koyama pointed out, there is a huge gap between digital-age and modern-day in terms of scope and time. With manipulation of just one translated word, Samuragouchi leaped from a limited specific digital gaming industry to a broader and more universal world. Simply put a modern-day Beethoven sounds a lot more significant than a digital-age one. If Samuragouchi came across with this idea for himself, as Koyama suggested, it is amazing that Samuragouchi had such a good sense of translation.

Continuing in this vein, the author also wonders how many people would even associate digital age with the gaming industry. The word "digital" has yet to be given a specific shared definition. In other words, images emerging from this word are varied and subjective. Its meaning is not so defined, whereas modern day implies unequivocal, which is probably why the phrase "a modern-day Beethoven" took root.

In the end, Samuragouchi was a fake Beethoven. But if he had been hearing impaired and created all the pieces of music as he had claimed, "a modern-day Beethoven" would have been a much more persuasive translation than "a digital-age" one, even if it had not been accurate.

\section{Conclusion}

Upon examining these five cases, the author has explored the possible truths inside mistranslations. Each case has its own specifics or intention behind it that generated a mistranslation. And each case is deeply associated with a fundamental question: How we can draw a line between a right and wrong translation? Or, what is translation? 
To help answer this fundamental question, four categories or methods of translation have been delineated (Torikai. 2013):

1. Word-for-word translation: It is the rendering of text from one language to another, one word at a time in sequence. It does not alter the grammar at all. It may not convey the sense of the original text. It is not always easy to get the meaning out of the translation.

2. Literal translation: It is also a faithful reproduction of the original text. Like word-for-word, it sticks to the source text, but literal translation is a little less rigid than word-for-word translations.

3. Sense-for-sense translation: It means translating the meaning of each whole sentence before moving on to the next. The sense is given priority over the form. Equivalence of meaning between the original and the target languages is more emphasized.

4. Free translation: It is even less restricted than sense-for-sense translation. It is not bound by the original text.

In actuality, these four methods are interwoven to create any translation. When it comes to dealing with a written text, it is possible to stick to one method of the four and decide a translation style. If focusing on conveying the content and taste of the original, the first and second methods are to be chosen, thereby a translator's own interpretation will be excluded as much as possible.

On the other hand, interpreting for a spoken language is a highly spontaneous language conversion so that selecting one method from the above-mentioned four is not realistic. Interpreters are most likely to focus on a sense-for-sense translation, incorporating here and there literal and free translations into it.

With each method, however, it is still not easy to judge any given translation as right or wrong. Judgments will always differ, depending on one's perspective.

This essay examined five cases of "mistranslation" both from translations and interpreting, and demonstrated that there are sometimes specific reasons and backgrounds that caused so-called "mistranslation". They were not simply errors. It also showed that interpreters could be a buffer for negotiations. They were sometimes blamed for the failure of negotiations. But often because of this buffer, negotiations could start afresh. It could be said that interpreters could have actually contributed to negotiations in a rather twisted way.

Having long been an interpreter, the author feels it is unfair, after the fact, to criticize others' mistranslations. However, pointing out translation errors could lead to figuring out common mistakes, and identifying cultural differences and politics behind the scenes. It will surely help improve the quality of translation and we should welcome the criticism. At the same time, we could benefit by being aware of the power of mistranslation, which may bring some possible truths to light. With this in mind, interpreters and translators could work even harder to produce the best translations possible, and continue striving to build stronger bridges of communication. This is, after all, the goal ${ }^{7}$.

\section{References}

Asahi Shimbun Morning Press. (2015, November 18). Keizai shinwa kenshou TPP: 1 Ikinari 'Saigotsuchou' bei he (Economic in-depth investigation of TPP: 1 Abrupt "Ultimatum" to the US). Tokyo: Asahi Shimbun Publishing Co.

Koyama, N. (2014). Petenshi to tensai-Samuragouchi jiken no zenbou (Con man and genius-Whole story of Samuragouchi Case) (pp. 182-184). Tokyo: Bungeishunju Ltd.

\footnotetext{
7 This paper is a revised and updated English version of "Goyaku no message-sei to shinjitsu-sei: shiron" written in Japanese, an article of Kotoba no Sekai 8th Issue 2016 by Koto Gengo Kenkyusho [Higher Language and Education Institute] of Aichi Prefectural University in Japan.
} 
Larimer, T. (2001). Songs of Silence-Video-game music maestro Samuragoch can't hear his own work. Retrieved from http://content.time.com/time/magazine/article/0.9171.1000781.00.html

Nakasone, Y. (2004). Jiseiroku—Rekishi houtei no hikoku toshite (Meditations-As defendant of history court). Tokyo: Shinchousha Publiching Co., Ltd.

Random House Unabridged Dictionary Second Edition. (1987). New York: Random House, Inc.

Sagara, T. (1991). Honyaku Yomoyama-banashi (Talk about various topics of translation). Tokyo: Japan Translation Federation.

Sodekawa, H. (2016). Goyaku no message-sei to shinjitsu-sei: Shiron (Possible truths inside mistranslations-An attempt at understanding mistranslations). Kotoba no Sekai [World of words] 8th Issue 2016 by Koto Gengo Kenkyusho [Higher Language and Education Institute] of Aichi Prefectural University in Japan.

Sodekawa, H. (2018). Douji tsuyaku ha yamerarenai (Cannot Stop Being a Simultaneous Interpreter). Tokyo: Heibonsha, Ltd.

The New Oxford dictionary of English. (1998). Oxford: Oxford University Press.

Torikai, K. (2004). Rekishi wo kaeta goyaku (Mistranslation that changed history). Tokyo: Shinchousha Publishing Co., Ltd.

Torikai, K. (2007). Tsuuyakusha to Sengo Nichibei Gaikou (Interpreters and Post-war Japan-US Diplomacy). Tokyo: Misuzu Shobo, Ltd.

Torikai, K. (Ed.). (2013). Yoku Wakaru Honyaku Tsuuyaku-gaku (Good guidelines to translation/interpreting studies). Minerva Shobo (pp. iii-iv). Kyoto: Minerva Shobo Co., Ltd.

Yabuki, S. (2004). Tanaka Kakuei no meisaku, Mao Zedong no meiwaku, Showa Tennou no meiwaku (Tanaka Kakuei’s Trouble, Mao Zedong's Trouble, and Showa Emperor's Trouble). Retrieved from http://www.21ccs.jp/china_quarterly/China_Quarterly_01.html 